\title{
RESEARCH INTO THE SOCIO-ECONOMIC IMPACT RESOURCE DEVELOPMENT IN NORTHERN CANADA PRIORITIES AND STRATEGIES OF INTEREST GROUPS
}

\author{
SCOTT MACDONALD \\ and \\ NORMAN GIESBRECHT \\ Addiction Research Foundation \\ Toronto, Ontario
}

\begin{abstract}
An examination of different interest groups (e.g. government, natives and industry) in Canada's north indicates that each group utilizes divergent strategies to research the socio-economic impact of rapid economic development. Furthermore, strategies and outcomes of research by each group generally reflect their priorities. On one extreme, studies sponsored by industry tend to downplay negative social impacts and stress positive economic gains from development. On the other extreme, the native people stress the social disruption of their traditional lifestyles and minimal economic benefits to be gained from development. The federal and provincial (Ontario) governments, in attaching priorities to different interest groups, have tended to implement the views of the majority of the population-those that benefit from the economic aspects of the development. Accordingly, negative social consequences related to northern resource development have only received cursory attention.
\end{abstract}

Private industry, the natives and governments all have divergent priorities and concerns with respect to the social impacts of resource development in northern Canada. This paper focuses on how each group has researched socio-economic impacts of these developments. The capability of each group to translate their respective findings into appropriate governmental policies is also explored, Northern Ontario is cited as an example of how governmental policies relating to possible negative social impacts evolve.

\section{PRIVATE INDUSTRY}

In the north, despite the complex network of governmental departments and agencies, there is evidence that the main determinants of economic growth are decisions made by private industry. Usually, decisions are based on factors such as the feasibility, size and location of the project; and, above allprofitability. Practically all social or socioeconomic impact studies conducted by industries have emphasized the economic rather than the social consequences of the proposed development (e.g., Ontario Hydro, 1977: Crawford, Roberts and Wright, 1974).

It is seldom in the interests of industry to spend time on adequately assessing negative social impacts of developments that may then require remedial measures. Adverse social conditions are often attributed to the historical situation of the north or are treated as a question of logistics; e.g., what facilities will be required to meet the problems? Projections of social impact are usually considered to bear a direct linear relationship with increases in population. Recommenda- 
tions for services and facilities such as medical services, social services or facilities within the criminal justice system are usually projected on the basis of expected population changes.

A report by Resources Management Consultants (1978) is an example of how a linear quantitative approach is utilized as they suggest future demands for services, such as education, medical services, housing and criminal justice, are expected to be directly proportional to projected population increases. Some of these effects (increased demands on services) may persist into the operations phase, but only to an extent consistent with the increased permanent regional population, according to the report (Resources Management Consultants Ltd., 1978, p. 125).

Unfortunately, a linear quantitative approach provides no allowances for the potentially unique impacts of the newcomers to development areas. For example, projections of crime rates on the basis of expected crude population growth may be an underestimation, especially if many of the newcomers are young, hard-drinking males. Projections of impact for the Alaskan pipeline demonstrate the importance of considering qualitative or structural components: for example, in Fairbanks, Alaska "changes in the structure of the health care delivery system and other aspects of the community caused the hospital and long-term care facility to be inadequate and changed the demands for health care manpower" despite earlier predictions that services would be adequate (Dixon, 1978, p. 158).

The Fairbanks experience also involved a dramatic increase in patients admitted to the mental health clinic ( 40 to $50 \%$ in 15 months) and a $100 \%$ increase in divorce actions in 24 months.

The report by Gemini North Ltd. (1974) on the Arctic Gas Pipeline emphasizes the problems of quantification in social impact studies and many of the conclusions are more guarded than is typical. They conclude the the impact of development: " is almost int possible to quantify, .... can both be visible and invisible, .... is often entirely uney. pected, and cannot be projected" (p. 543) Thus they report that: "crimes of violence alcohol abuse, child neglect and similar socia disorders appear to increase out of propor. tion with the rate of population increase under the impact of development" (p. 533).

The benefits to society produced by resource extraction, plus the income generated for corporations, give companies a great deal of power. For example, the value of our forest industry to our standard of living is probably the most powerful incentive for development: "The forest industry in $\mathrm{On}$ tario pays directly and indirectly more tham 300 million dollars a year in municipal, provincial and federal taxes. Its expenditure for goods and services to support woodlands and mill operations in the province are estimated at 2 billion dollars annually. In Northwestern Ontario, the forest industry accounts for $73 \%$ of all manufacturing and, in addition, provides employment for some 4,000 in logging. Forestry assumes a vital role in small communities throughout much of Northert and Central Ontario. These communities depend upon the wages and taxes provided by forestry activities in both private and publis sectors. They can only continue to exist and develop in the future if their economic base, the forest, is maintained in a productive state" (Municipal Advisory Committer, $1979, \mathrm{p}, 21)$. It is these types of benefits that are most powerful in dictating continued economic development, and they have resulted in the government's prodevelopment policies.

Some have reinforeed that it is generally the corporate interests that dictate economite developments in the north. Dosmond (1975) eloquently describes the situation in the Northwest Territories: "It is now clear however, that the national interest has bell defined to a large extent by short term cof porate interests. Indeed, so long as mulp 
attonal corporations have a near monopoly on information and influence pertaining to significant development decisions, then narional policy for the north can only reflect corporate goals for the north." Further, puprioski (1978) states that: "In the past, conomic development proceeded as if it was intrinsically good for everyone." Generally, both social and environmental concerns have been downplayed by corporations who plan northern development.

Corporations utilize more governmental channels than other groups to affect governmental decision and have far greater financial resources for advertising promotion, and other methods of persuasion. In short, the political and economic dynamics of resource development have permitted corporate industries to have the greatest influence in social impact studies designed to reduce negative impacts in resource communities.

\section{THE NATIVES}

The ethnic and cultural compositions of the host community affected by economic developments vary, but in northern Canada, the aboriginal populations often represent the largest group. In contrast to studies conducted by industry, the negative social impact of development is emphasized by native interest groups. Loss of independence or social identity due to the erosion of traditional lifestyles is the key issue in reports sponsored by native groups. Spaulding (1967) claims that the new economic conditions, coupled with the diminishing resources that sustained Indian life, have encouraged native dependence upon whites.

The methods and approaches of reports iponsored by native groups are quite different from those sponsored by government and industry. First reports in general are iparse, probably because of limited financial resources; second, they tend to rely heavily on anecdotal material; and finally, they rarely use quantitative data. Even in government reports, native viewpoints are frequently presented in an anecdotal format (Hartt,
1978). Additionally, few natives are contrdent in public forums and their viewpoints are not always adequately presented (Tester, 1978).

Alienation from the existing framework of decision-making, though common to many groups in northern Ontario, is a particular problem for the native peoples (Macdonald, Eakins and McKenzie, 1980). For them, the problem is not simply one of not being listened to by decision-makers, but stems from a more basic problem, a fundamentally different pattern of political development experience. Nowhere is this more visibly evident than in the Nishawbe-Aski Declaration and their submission to the Royal Commission on the Northern Environment by the Grand Council Treaty No. $9(1976,2)$ : " As your society is structured today, this puts us on different sides of the issue. We are adversaries within the legal framework of this country. The adversary system is one with which your judicial process is familiar and one with which the code of law of our people is unfamiliar."

The growing visibility of native interests in recent years is largely related to their increased organizational and vocal abilities, and in particular through the impetus of increased resource development activity such as the Reed proposal to lumber 19,999 square miles of forest tract land north of $50^{\circ}$. Government willingness to involve native groups in decision-making has been quite limited despite policy statements to the contrary. In fact, the record suggests that despite guidelines for land use planning set down by the Ministry of Natural Resources in 1974 requiring that those most affected by land use activities be involved at all stages of the process, participation in such processes has been limited to being informed. To a large extent consultation with such groups has remained almost non-existent. Even a previous Minister of Natural Resources has publicly conceded that the natives have not been fully consulted in resource development decisions (Richard, 1977, p. 19). The natives are not 
opposed to development per se; in fact, many believe that their future is dependent on a strong economic base. But, full participation in all stages of the planning and implementation process is a necessary prerequisite for the natives. They want some element of control over economic plans at a community level: in other words, development of their own local government. "Local government means that the band councils handle all development programmes, committees and other projects in the community. The band councils must be supported with all available development resources from government agencies" (Richard, 1977, p. 3). Also, northern development must consider traditional land use patterns and possible alteration of social arrangements.

Politically, the natives find themselves in the unfortunate situation of dealing with land claims on a federal level and with resource development problems on a provincial level. Frapping and fishing rights are handled through the Department of Natural Resources while jurisdictional issues must be handled at a federal level. No one ministry has the authority to deal with the totality of concerns expressed by the natives, concerns about cultural erosion and social disruption caused by resource developments. The absence of effective governmental mechanisms to deal with such concerns is presently a major deficiency of resource decisions.

\section{GOVERNMENTAL RESPONSES}

Studies sponsored by government tend to favour economic prosperity, however, due to the various departments and levels of government, this generalization is not always applicable. Governments are in the unenviable position of representing a wide spectrum of views, including presentation of negative social impacts of developments. Strong pressures to promote economic prosperity usually overrides thorough and balanced descriptions of social impacts, If negative social consequences are described as linked with development, remedial measures to reduce these effects may be discussed however, such measures are rarely im plemented. When such measures are in. plemented, it is almost always at a local level through the diligence of community pressure groups.

The emphasis on economic objectives can be observed in a number of governmenta reports which often stress the economic rather than social impact of the development and conclude that social change caused by the project was not drastic (Department of Indian and Northern Affairs, 1976; Bisse, 1970; and Scott, 1973).

On the other hand, a growing number of studies have highlighted the destructive forces of social and cultural conditions which accompany rapid development in northern communities, pointing out, for example, that the project raised serious and complex social issues, yet no social impact study had been conducted before the project went ahead (Gibson, 1978). Berger (1977) has observed that: "social impact assessment is often merely window-dressing for decisions already made and only serves to discuss remedial measures for local negative impacts."

In Ontario, for example, imbalances of political, economic and social resources have resulted in the south largely dictating the nature of development in the north. The north has been described as primarily an $e x$. tractive economy, producing goods and services for the benefit of southern consumer (Weller, 1977).

There are some recent developments in 0 : tario that are designed to reduce this alienttion. The recently established Ministry of Northern Affairs (1977) should facilitate an overall strategy for resource development: and the Environmental Assessment Ad (1975) provides a formalized and visible pro cess for public participation in the assessment of resource development projects. The ent vironment as defined in the Act, include "the social, economic and cultural condi 
forns that influence the life of man or the community." Therefore, this is an appropriate forum for voicing concerns and raising possible measures to investigate negative social consequences produced by the rapid development.

Unfortunately, there are several factors that prevent this latter forum from adequateIy representing social concerns (MacDonald et al. 1980). First, although the definition of environment under the Act is broad (to include social conditions), the capability of this Ministry to address such issues is questionable, because its mandate is confined to the physical enviromment. Second, the proponents of the resource development are expected to prepare the assessment. This mandate of responsibility can create a conflict of interest whereby the industry may attempt to minimize their own costs (and therefore a thorough assessment might not be conducted) and also minimize any negative repercussions of the development. The party with the greatest resources (financial and otherwise) gives obvious a priori advantage (Emond, 1977). Third, public participation occurs only after the assessment is complete, and at this stage major modifications are unlikely. These drawbacks, coupled with no publicly available guidelines for the exercise of the Ministry's power and authority, severely limit the power of the Act to reduce rocial impacts.

\section{CONCLUSIONS}

Industry, the northern native inhabitants and the different levels of government all have different priorities related to investigations of negative social impacts of northern development. Industries have often utilized a linear quantitative approach to social impact assessment, which tends to downplay any negative associated consequences. Furthermore, the large financial resources of industries, the political dynamics of northern development, and the inadequacies of the Environmental Assessment Act (in Ontario) have contributed towards industries having the greatest impact on social impact assessment and measures designed to reduce negative social consequences. On the opposite extreme, the native inhabitants have meagre resources for studying social consequences; and the nature of the Environment Assessment Act does not adequately address social impact. Governmental studies tend to emphasize economic aspects of resource development, and often call for greater native participation in the labour force. Though the governments often express sympathy with native concerns, typically only poor measures are designed to incorporate these concerns in the decision-making process.

Research into the social impacts of northern development appear to be exemplified by vested interests: research is designed to confirm "a priori" goals. Even when "outsiders" conduct research (which is rare) they are hired by one or more interest groups and must report to them. Unlike much research, such as research into diseases, where all parties have the same goal; the objectives or goals in social impact research are divergent often leading to equivocal results. Vested interests of different groups have served to cloud and confuse the true nature of the social impacts related to northern resource development.

\section{RÉSUMÉ}

Lorsqu'on étudie les différents groupes d'intérêts (gouvernements, autochtones, industries, etc.) dans le Nord du Canada, on constate que chacun d'entre eux utilise des stratégies divergentes pour analyser les répercussions socio-économiques d'une croissance économique rapide. En outre, les stratégies et les résultats de recherche de chaque groupe reflètent en 
général leurs objectif́s prioritaires. D'une part, les études parrainées par l'industrie tendent à sous-évaluer les répercussions sociales négatives et à mettre surtout l'accent sur les avantages économiques de l'expansion alors que d'autre part, les autochtones dénoncent la perturbation de leur mode de vie traditionnel et soulignent les avantages économiques minimaux découlant du développement. Les gouvernements fédéral et provincial (Ontario) ont eu tendance à se conformer aux voeux de la majorité de la population-ceux qui tirent profit des retombées économiques de la croissance-dans l'établissement de l'ordre de priorité des mesures destinées aux différents groupes d'intérẻts. Par conséquent, les effets sociaux négatifs découlant de la mise en valeur des ressources dans le Nord n'ont fait l'objet que d'un examen superficiel.

\section{REFERENCES}

Berger. T,R. Nonthern frontier, northern homeland: The report of the Mackenzle Valley Pipeline Inquiry, Vol. I, Ottawat Department of Supply and Services, 1977 .

Bissett, D. Socib-economic implications of Eskimo employment in the Baffinland Iron Mines Project. Ottawat Northern Development Branch, Department of Indian Affairs and Norihern Development, 1970.

Crawford, C.S., Roberts, J.E, and Wright, D.R.C. The social and economic impacts of the proposed Seven Mile Hydro-Electric Project. Vancouver, B.C.: Hydro and Pawer Authority, 1974.

Dixon, M. What happened to Fairbanks? Boulder, Colorado: Westview Press, 1978.

Dasmond, E.J. The national interest. Toronto: MeClelland and Stewan Led., 1975.

Emond, D.P. Notes on decisional modets for northem resource development decisions, Prepared for the Royal Commission on the Northern Environinen, Toronto, 1977.

Foothills Pipe Lines L.td. Part 5-Public interest, socio-economic statement. Prepared for the Department of Indian Affain and Northern Development, Ottawa, 1975.

Gemini North Ltd. Sacial and economic impact of the proposed Arctic Gas Pipeline in northern Canada. Prepared for the Canadian Arctic Gas Pipelines I.1d., 1974 .

Gibson, R. Srrathcona Sound Mining Project: A case study of decision making (Science Council of Canada, Background Study No, 42). Ottawa: Minister of Supply and Services, 1978.

Grand County Treaty No. 9, The lund and the people are one, 1976.

Hartt, P. Interim report and recommendations. Toronto: Royal Commission on the Northern Environment, 1978 .
Indian and Northern Affairs. Anmal Repori, 1975.1975. Ottawa: Department of Indian and Northers Affairs, 1976 .

MacDonald, S., Eakins, B. and MeKenzie, D. A seiecias overview of Onfario's public decisional frame work of northern primary nesource developman Toronto: The Royal Commission on the Northem Environment, 1980.

Municipal Advisory Committec on Northwestern Ontarte Proceedings of Forest Management Seminar, 1979

Ontario Hydro. Socio-economic foctors. (Prepated for the Royal Commission on Electric Power Planinin with respect to Public Information Heariagl. 1977.

Paprioski, D. Weighting conflicting concerns in froatia development. Natural Resoures Fortum, 2, 3 $257-270,1978$.

Resources Manaesment Consultants L.td. Draft fial environmental impact assessment for Imperial oit Lid., Cold Lake Proiect, Vol. II. Socio cconomi Impact Assessment. Edmonton, 1978.

Richard, A. Pipcline plan worries. Chronical Joumd, December 5, 1977 ,

Scott, M. The socro-economic impact of the Poinied Mountain Gas Field. Ottawat Northern Pohey and Program Planning Branch, Department of Indiat and Northern Affaits, October 1973.

Spaulding. P. The social imtegration of a northern cont munity: White mythology and Metis realisy, in A. David (Ed.), A northern cillemana: nference papers. Bellingham, Washington: Western Wash ington State Press, 1967.

Tester. F. Social impuct assessment: Approuchine the Fourth World. Caleary: Kanaskis Centre for Ea virorimental Research and Faculiy of Socil Welfare, University of Calgary, 1978.

Wellet, G, R. Hinterland polities: The eases of North western Ontario. Canadian Journal of Rolune Science, 1977, X, 4, 727.754. 